\title{
Short communication \\ Nitrogen use efficiency of maize (Zea mays L.): Organic versus inorganic fertilisers effects
}

\author{
AyanfeOluwa Olufemi Emmanuel $* 1$ and AdeOluwa Oluseyi Olugbenga ${ }^{2}$ \\ ${ }^{1}$ Department of Agriculture, Federal College of Agriculture, P.M.B 5029, Moor Plantation, Ibadan, Nigeria. \\ ${ }^{2}$ Department of Agronomy, University of Ibadan, Ibadan, Nigeria. \\ [Received: December 15, 2017 Accepted: February 15, 2018]
}

\begin{abstract}
Nitrogen Use Efficiency (NUE) of a crop could be an important index in determining efficiency of a fertiliser. This study presents the investigation of NUE of maize; comparing organic fertiliser and mineral fertiliser NPK. The field trials were conducted in the rainy seasons of 2013 and 2014, using a randomised complete block design with three replicates. Experimental treatments were 0, 60, 90, 120, 150 and $180 \mathrm{~kg} \mathrm{~N} \mathrm{ha}^{-1}$ Accelerated compost (AC) with a commercial name OBD-plus which is a recent material in Nigeria), conventional compost ' $C C^{\prime}$ ' $\left(60 \mathrm{~kg} \mathrm{~N} \mathrm{ha}^{-1}\right)$ and NPK 15-15-15 mineral fertiliser (60 $\mathrm{kg} \mathrm{N} \mathrm{ha}^{-1}$ ). Data on maize grain yield, Fertiliser $N$ recovery (NR) and Fertiliser Utilization Efficiency (UE) as well as post-cropping soil $N$ were subjected to statistical analysis. The $60 \mathrm{~kg} \mathrm{~N} \mathrm{AC}$ treated plots resulted in the highest significant mean NR (54.3\%) and UE $\left(42.3 \mathrm{~kg} \mathrm{~kg}^{-1}\right)$ in the two years, with improved soil $N$. Therefore, the AC considered in this study would be best applied at $60 \mathrm{~kg} \mathrm{~N}$ ha-1 for maize production in the Alfisols. This would optimize fertiliser utilization and reduce $N$ loss, thus mitigating environmental pollution.
\end{abstract}

Keywords: Alfisol, compost optimization, effective microorganisms, organic wastes, Zea mays

The population of the world has been projected to be 8.3 billion in 2030 (UNDESA, 2015). Feeding such population requires increasing food crop production with pragmatic methods of fertiliser application that would supply optimal nutrients to crop and also protect the soil. However, inappropriate fertiliser application could undermine nutrients' availability and retention in soils (Lory and Massey, 2006; Chen et al., 2009; Dong et al., 2012). Nitrogen is a usual limiting nutrient element for cereal production (Amanullah and Almas, 2009; Wanyama et al., 2015; Zingore, 2016), maize is not exempted. This is because it is needed in higher amount relative to other primary nutrients and the cost per unit quantity is highest among the primary nutrients. Meanwhile, nitrogen being very prone to leaching and volatilisation, could readily pollute water bodies and increase nitrous oxide in the atmosphere, thereby contributing to global warming (Barbanti et al., 2010; Butterbach-Bahl et al., 2013; Ghaly and Ramakrishnan, 2015; Kanter et al., 2016). Therefore, there is a need to evaluate the amount of nitrogen to be applied with the nutrient utilization of a particular crop.

Maize is an important cereal that is widely cultivated globally (Christian et al., 2012) and exhibits high response to fertiliser among other cereals (Kelly et al., 2005; Kelly, 2006). Hence, there is a need to compare fertiliser types and rates from organic and mineral sources with respect to their influence on Nitrogen use efficiency (NUE) and residual soil nitrogen, using maize as a test crop. Thus, this research work investigated the NUE of maize in response to application of different types and rates of organic fertilisers (compost) and mineral fertiliser.

This trial was conducted at the Federal College of Agriculture, Ibadan, Nigeria (Lat. $7^{\circ} 22.5^{\prime} \mathrm{N}$ and Long. $3^{\circ} 50.5^{\prime} \mathrm{E}$ ) on an Alfisol (Smyth and Montgomery, 1962). The field trials were conducted in the rainy seasons of 2013 and 2014, between May and July. The treatments were accelerated compost (AC) at $0,60,90,120,150$ and $180 \mathrm{~kg}$ $\mathrm{N} \mathrm{ha}^{-1}$, conventional compost (CC) at $60 \mathrm{~kg} \mathrm{~N} \mathrm{ha}^{-1}$ and NPK 15-15-15 mineral fertiliser at $60 \mathrm{~kg} \mathrm{~N} \mathrm{ha}^{-1}$. The $\mathrm{N}$ rate treatments were calculated based on the $\mathrm{N}$ content of the fertilizer materials. Experimental design was randomized complete block with three replicates. The rate $\left(60 \mathrm{~kg} \mathrm{~N} \mathrm{ha}^{-1}\right)$ used for the mineral fertiliser and $\mathrm{CC}$ was the recommended rate, while $\mathrm{AC}$ was in five levels, being a recent material in Nigeria.

\footnotetext{
*Email: ayanfeoluwaolufemi@gmail.com
} 
The accelerated compost (OBD-plus) evaluated in this study was obtained from Gateway Fertiliser Company, based at Abeokuta in Ogun State, Nigeria. The raw materials comprised of market and abattoir wastes and method of composting involves the artificial introduction of some microorganisms, which speed up the rate of decomposition of organic materials, to enable the compost matures in a month. The conventional compost which serves as a check was obtained from Alesinloye Compost Company, based in Ibadan, Oyo State, Nigeria. The raw materials of the conventional compost comprised of market and abattoir wastes and the composting relies on the microorganisms from the environment alone and takes about two months to mature. The accelerated compost cost $\$ 120$ $\mathrm{kg}^{-1}$ (equivalent of $\$ 0.33 \mathrm{~kg}^{-1}$ ), while the conventional compost cost $\$ 70 \mathrm{~kg}^{-1}$ (equivalent of $\$ 0.19 \mathrm{~kg}^{-1}$ ). The compost treatments were applied a week before planting using drilling method and the mineral fertiliser at two weeks after planting using band method. The land preparation was carried out through ploughing and harrowing. Maize seeds were sown at two seeds per hole but thinned to one, while very few missing stands were supplied. Weeding was carried out twice before harvesting. Twelve soil samples were randomly collected at the depth of $0-15 \mathrm{~cm}$ and bulked together from each experimental site $\left(360 \mathrm{~m}^{2}\right.$ area of land per site) prior to the commencement of the experiments. The bulked soil samples were air-dried and sieved with $2 \mathrm{~mm}$ mesh sieve and another portion with 0.5 $\mathrm{mm}$ mesh sieve (for nitrogen and organic carbon analyses). Chemical analyses of the two compost (Table 1) were carried out using standard procedures (Olsen and Dean, 1965; Okalebo et al., 1993; Bremner, 1996; Thomas, 1996).

The physical and chemical analyses of the pre-treated soils were also carried out using standard procedures. Soil $\mathrm{pH}$ was determined in distilled water at a 1:2 soil to water ratio using electrometric method (Thomas, 1996). Total N content was determined by the macro-Kjeldahl digestion procedure (Bremner, 1996). Available $\mathrm{P}$ was extracted by Bray P 1 method (Bray and Kurtz, 1945), colour developed by the Molybdenum blue colour method (Murphy and Riley, 1962) and the content read with a spectrophotometer (Model CE 2041). Exchangeable bases (Ca, Mg, K and $\mathrm{Na}$ ) were extracted with $1.0 \mathrm{~N}$ ammonium acetate (Hendershot et al., 1993). Thereafter, the amounts of $\mathrm{K}$ and $\mathrm{Na}$ in the

Table 1: Chemical analysis of the two compost used for the study

\begin{tabular}{|c|c|c|c|c|c|c|c|c|c|c|c|c|}
\hline Parameter & $\mathrm{pH}\left(\mathrm{H}_{2} \mathrm{O}\right)$ & Total Carbon & $\mathbf{N}$ & $\mathbf{P}$ & $\mathbf{K}$ & Ca & $\mathbf{N a}$ & $\mathrm{C}: \mathrm{N}$ ratio & $\mathbf{F e}$ & $\mathbf{C u}$ & Mn & $\mathbf{Z n}$ \\
\hline & \multicolumn{8}{|c|}{ 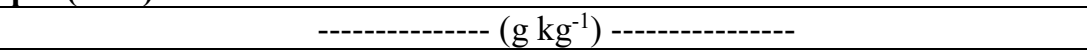 } & \multicolumn{4}{|c|}{------ $\mathrm{mg} \mathrm{kg}^{-1}$} \\
\hline $\mathrm{AC}$ & 5.9 & 150 & 10.9 & 10 & 3 & 140 & 1 & 14 & 1321 & 61 & 405 & 146 \\
\hline $\mathrm{CC}$ & 9.7 & 170 & 12 & 8 & 17 & 240 & 4 & 14 & 6053 & 11 & 393 & 1.5 \\
\hline
\end{tabular}

(AC; Accelerated compost, CC; Conventional compost)

Table 2: Physical and chemical characteristics of soil in the experimental field

\begin{tabular}{|c|c|c|}
\hline Parameters & 2013 & 2014 \\
\hline $\mathrm{pH}\left(\mathrm{H}_{2} \mathrm{O}\right) 1: 1$ & 6.2 & 6.1 \\
\hline Organic $\mathrm{C}\left(\mathrm{g} \mathrm{kg}^{-1}\right)$ & 7.2 & 9.1 \\
\hline Total $\mathrm{N}\left(\mathrm{g} \mathrm{kg}^{-1}\right)$ & 0.4 & 0.9 \\
\hline Avail. $\mathrm{P}\left(\mathrm{mg} \mathrm{kg}^{-1}\right)$ & 8 & 4 \\
\hline \multicolumn{3}{|l|}{ Exchangeable cations $\left(\mathrm{cmol} \mathrm{kg}^{-1}\right)$} \\
\hline $\mathrm{Ca}^{2+}$ & 1.8 & 1.8 \\
\hline $\mathrm{Mg}^{2+}$ & 0.7 & 1.1 \\
\hline $\mathrm{K}^{+}$ & 0.4 & 0.4 \\
\hline $\mathrm{Na}^{+}$ & 0.4 & 0.5 \\
\hline Ex. Acidity $\left(\mathrm{cmol} \mathrm{kg}^{-1}\right)$ & 0.1 & 0.1 \\
\hline $\operatorname{ECEC~}\left(\mathrm{cmol} \mathrm{kg}^{-1}\right)$ & 3.4 & 3.9 \\
\hline \multicolumn{3}{|l|}{ Extractable micronutrients $\left(\mathrm{mg} \mathrm{kg}^{-1}\right)$} \\
\hline $\mathrm{Mn}$ & 423 & 157 \\
\hline $\mathrm{Fe}$ & 191 & 133 \\
\hline $\mathrm{Cu}$ & 3 & 3 \\
\hline \multicolumn{3}{|l|}{ Particle size $\left(\mathrm{g} \mathrm{kg}^{-1}\right)$} \\
\hline Sand & 840 & 876 \\
\hline Silt & 108 & 24 \\
\hline Clay & 52 & 100 \\
\hline Textural class (USDA) & Loamy sand & Loamy sand \\
\hline
\end{tabular}


filtrates were determined using flame emission photometer (Jenway PFP7 Model), while Ca and Mg were determined using EDTA titration method (Pawar et al., 2009). Exchangeable acidity was extracted with $1 \mathrm{~N} \mathrm{KCl}$ (Thomas, 1982) and determined by titration with $0.01 \mathrm{~N} \mathrm{NaOH}$ using phenolphthalein indicator. The Effective Cation Exchange Capacity (ECEC) was calculated as the total sum of exchangeable bases and total exchangeable acidity (Chapman, 1965).

Extractable micronutrients ( $\mathrm{Fe}, \mathrm{Cu}, \mathrm{Mn}$ and $\mathrm{Zn}$ ) were extracted by Mehlich III method (Mehlich, 1984) and reading done on Atomic Absorption Spectrophotometer (AAS) (Model Buck scientific NV 210/211). Organic Carbon was determined by the procedure of Walkley and Black using the dichromate wet oxidation method (Nelson and Sommers, 1996). Particle size distribution analysis was carried out by Bouyoucos hydrometer method (Gee and Or, 2002) using sodium hexametaphosphate as the dispersing agent.

The results of the analyses are shown in Table 2 . The analyses showed that the soil in both years were low in $\mathrm{N}$; $0.4 \mathrm{~g} \mathrm{~kg}^{-1}, \mathrm{P} ; 8$ and $4 \mathrm{mg} \mathrm{kg}-1$ and organic carbon; 7.2 and
$9.1 \mathrm{~g} \mathrm{~kg}^{-1}$, marginal in $\mathrm{K} ; 0.4 \mathrm{cmol} \mathrm{kg}^{-1}$ (FFD, 2012) and the textural class was loamy sand according to USDA textural triangle (Soil Survey Division Staff 1993).

The plot size was $3.3 \times 3.3 \mathrm{~m}$, planting spacing was 75 x $25 \mathrm{~cm}$ and one plant per stand was maintained. The space between the plots and blocks were 0.5 and $1 \mathrm{~m}$ respectively. The maize variety used as test crop was an extra early maturing hybrid; TZEE1 14 x TZEE1 57 x TZEE1 12. Data were collected on grain yield, while $\mathrm{N}$ content and uptake were determined (Bremner, 1996; Sharma et al., 2012)

The Fertiliser N Recovery (NR) was obtained by difference method of Varvel and Peterson (1990) and Fertiliser Utilization Efficiency (UE) by Schenk (2006) as follows:

Fertiliser N Recovery (NR) $=(\mathrm{NF})-(\mathrm{NC}) / \mathrm{R}$ x $100 \%$ $\mathrm{NF}=$ Total $\mathrm{N}$ uptake in maize from $\mathrm{N}$ fertilized plots $\mathrm{NC}=$ Total $\mathrm{N}$ uptake in maize from unfertilized plots $\mathrm{R}=$ Rate of fertiliser $\mathrm{N}$ applied

Fertiliser Utilization Efficiency $(\mathrm{UE})=(\mathrm{YF})-(\mathrm{YC}) / \mathrm{R} \mathrm{kg}$ $\mathrm{kg}^{-1}$

Where $\mathrm{YF}=$ Yield from $\mathrm{N}$ fertilized plots

Table 2: NUE of maize in response to $\mathrm{AC}$ in a field trial in 2013

\begin{tabular}{|c|c|c|c|c|c|c|}
\hline Treatments & $\begin{array}{l}\text { Applied N } \\
\left(\mathbf{k g ~ h a} \mathbf{~ h}^{-1}\right)\end{array}$ & $\begin{array}{l}\text { Grain yield } \\
\left(\mathrm{kg} \mathrm{ha}^{-1}\right)\end{array}$ & $\begin{array}{c}\text { N-content } \\
(\%)\end{array}$ & $\begin{array}{l}\text { N-uptake } \\
\left(\mathrm{kg} \mathrm{ha}^{-1}\right)\end{array}$ & $\begin{array}{c}\text { Fertiliser } N \text { recovery } \\
(\%)\end{array}$ & $\begin{array}{c}\text { Utilization efficiency } \\
\left(\mathrm{kg} \mathrm{kg}^{-1}\right)\end{array}$ \\
\hline Control & 0 & 2292 & 1.5 & 34.4 & - & - \\
\hline $60 \mathrm{~kg} \mathrm{~N} \mathrm{ha}^{-1} \mathrm{NPK}$ & 60 & 3954 & 1.8 & 71.2 & 61.4 & 27.7 \\
\hline $60 \mathrm{~kg} \mathrm{~N} \mathrm{ha}^{-1} \mathrm{CC}$ & 60 & 3643 & 1.2 & 43.7 & 15.6 & 22.5 \\
\hline $60 \mathrm{~kg} \mathrm{~N} \mathrm{ha}^{-1} \mathrm{AC}$ & 60 & 4042 & 1.7 & 68.7 & 57.3 & 29.2 \\
\hline $90 \mathrm{~kg} \mathrm{~N} \mathrm{ha}^{-1} \mathrm{AC}$ & 90 & 2942 & 1.4 & 41.2 & 7.6 & 7.2 \\
\hline $120 \mathrm{~kg} \mathrm{~N} \mathrm{ha}^{-1} \mathrm{AC}$ & 120 & 4176 & 1.6 & 66.8 & 27.1 & 15.7 \\
\hline $150 \mathrm{~kg} \mathrm{~N} \mathrm{ha}^{-1} \mathrm{AC}$ & 150 & 4139 & 1.8 & 74.5 & 26.8 & 12.3 \\
\hline $180 \mathrm{~kg} \mathrm{~N} \mathrm{ha}^{-1} \mathrm{AC}$ & 180 & 4413 & 1.9 & 84.3 & 27.8 & 24.5 \\
\hline $\operatorname{LSD}_{(0.05)}$ & & 609 & & 9.9 & 14.5 & 9.1 \\
\hline
\end{tabular}

(NPK; NPK 15-15-15, AC; Accelerated Compost, CC; Conventional Compost

$\operatorname{LSD}_{(0.05)}$; Least significant difference at $5 \%$ probability)

Table 3: NUE of maize in response to AC in a field trial in 2014

\begin{tabular}{|c|c|c|c|c|c|c|}
\hline Treatments & $\begin{array}{c}\text { Applied N } \\
\left(\mathrm{kg} \mathrm{ha}^{-1}\right)\end{array}$ & $\begin{array}{c}\text { Grain yield } \\
\left(\mathrm{kg} \mathrm{ha}^{-1}\right)\end{array}$ & $\begin{array}{c}\text { N-content } \\
(\%)\end{array}$ & $\begin{array}{l}\text { N-uptake } \\
\left(k^{-} h^{-1}\right)\end{array}$ & $\begin{array}{c}\text { Fertiliser } \mathrm{N} \text { recovery } \\
(\%)\end{array}$ & $\begin{array}{c}\text { Utilization efficiency } \\
\left(\mathrm{kg} \mathrm{kg}^{-1}\right)\end{array}$ \\
\hline Control & 0 & 1917 & 0.8 & 15.0 & - & - \\
\hline $60 \mathrm{~kg} \mathrm{~N} \mathrm{ha}^{-1} \mathrm{NPK}$ & 60 & 2968 & 1.2 & 35.5 & 34.3 & 49.5 \\
\hline $60 \mathrm{~kg} \mathrm{~N} \mathrm{ha}^{-1} \mathrm{CC}$ & 60 & 2759 & 1.1 & 30.5 & 25.9 & 46.0 \\
\hline $60 \mathrm{~kg} \mathrm{~N} \mathrm{ha}^{-1} \mathrm{AC}$ & 60 & 3325 & 1.3 & 45.7 & 51.2 & 55.4 \\
\hline $90 \mathrm{~kg} \mathrm{~N} \mathrm{ha}^{-1} \mathrm{AC}$ & 90 & 3958 & 1.6 & 63.2 & 53.5 & 44.0 \\
\hline $120 \mathrm{~kg} \mathrm{~N} \mathrm{ha}^{-1} \mathrm{AC}$ & 120 & 3020 & 1.2 & 36.6 & 18.0 & 25.2 \\
\hline $150 \mathrm{~kg} \mathrm{~N} \mathrm{ha}^{-1} \mathrm{AC}$ & 150 & 3526 & 1.4 & 49.8 & 23.2 & 23.5 \\
\hline $180 \mathrm{~kg} \mathrm{~N} \mathrm{ha}^{-1} \mathrm{AC}$ & 180 & 3394 & 1.4 & 46.9 & 17.8 & 18.8 \\
\hline $\operatorname{LSD}_{(0.05)}$ & & 451 & & 12.4 & 17.0 & 7.2 \\
\hline
\end{tabular}

(NPK; NPK 15-15-15, AC; Accelerated Compost, CC; Conventional Compost

$\operatorname{LSD}_{(0.05)}$; Least significant difference at $5 \%$ probability) 
$\mathrm{YC}=$ Yield from unfertilized plots and

$\mathrm{R}=$ Rate of fertiliser $\mathrm{N}$ applied

The post cropping soil was analysed to determine the soil total nitrogen using Kjeldahl digestion procedure (Bremner, 1996). The data obtained were statistically analysed using ANOVA at $\alpha_{0.05}$.

The NUE of maize in response to the different fertilizer treatments in 2013 is shown in Table 2. The plot treated with NPK at $60 \mathrm{~kg} \mathrm{~N}^{-1}$ resulted into the highest NR $(61.4 \%)$, which was not significantly $(p<0.05)$ different from AC, $60 \mathrm{~kg} \mathrm{~N} \mathrm{ha}^{-1}$ (57.3\%), while CC, $60 \mathrm{~kg} \mathrm{~N} \mathrm{ha}^{-1}$ had the least value $(15.6 \%)$. The AC, $60 \mathrm{~kg} \mathrm{~N}^{-1}$ had highest UE $\left(29.2 \mathrm{~kg} \mathrm{~kg}^{-1}\right)$, but the difference was not significant compared with other treatments, except $90-150 \mathrm{~kg} \mathrm{~N} \mathrm{ha}^{-1}$ AC with 7.2 - $15.7 \mathrm{~kg} \mathrm{~kg}^{-1}$. In 2014 trial (Table 3), AC, 90 $\mathrm{kg} \mathrm{N} \mathrm{ha}^{-1}$ resulted into the highest NR (53.5\%) but was not significantly different from $60 \mathrm{~kg} \mathrm{~N}^{-1} \mathrm{AC}(51.2 \%)$, while AC, $180 \mathrm{~kg} \mathrm{~N} \mathrm{ha}^{-1}$ had the least value (17.8\%). The highest UE of $55.4 \mathrm{~kg} \mathrm{~kg}^{-1}$ was obtained from AC, $60 \mathrm{~kg} \mathrm{~N} \mathrm{ha}^{-1}$, though not significantly different from NPK, $60 \mathrm{~kg} \mathrm{~N} \mathrm{ha}^{-1}$ (49.5 kg kg-1), it was higher than other treatments. On the average, the plot treated with $\mathrm{AC}, 60 \mathrm{~kg} \mathrm{~N}^{-1}$ had the highest significant NR (54.3\%) and UE (42.3 $\left.\mathrm{kg} \mathrm{kg}^{-1}\right)$ in the two years, followed by NPK, $60 \mathrm{~kg} \mathrm{~N} \mathrm{ha}^{-1}$ plot (47.9 and $38.6 \mathrm{~kg} \mathrm{~kg}^{-1}$, respectively). In terms of post cropping soil total $\mathrm{N}$ (Figure 1), the AC, $60 \mathrm{~kg} \mathrm{~N} \mathrm{ha}^{-1}$ resulted into values of 1.4 and $1.2 \mathrm{~g} \mathrm{~kg}^{-1}$ in 2013 and 2014, respectively, which compared favourably with other levels of AC (1.4-2.0 and $1.0-1.4 \mathrm{~g} \mathrm{~kg}^{-1}$, respectively) and CC (1.3 and $\left.1.0 \mathrm{~g} \mathrm{~kg}^{-1}\right)$ but significantly higher than the NPK with 0.8 and $0.9 \mathrm{~g} \mathrm{~kg}^{-1}$ in 2013 and 2014, respectively.

The $\mathrm{AC}$ at $60 \mathrm{~kg} \mathrm{~N} \mathrm{ha}^{-1}$ treated maize resulted into optimum NR (among the different rates of AC) of $54.3 \%$, which was more than double of each of the AC, $180 \mathrm{~kg} \mathrm{~N}$ $\mathrm{ha}^{-1}$ and CC, $60 \mathrm{~kg} \mathrm{~N} \mathrm{ha}^{-1}$ and also better than the NPK in the two years. Also, in terms of UE, AC at $60 \mathrm{~kg} \mathrm{~N} \mathrm{ha}^{-1}$ treated maize gave the highest value among all the treatments and the UE decreased with other $\mathrm{AC}$ rates, in the two years. This result is in agreement with the finding of Pikul et al. (2005) where $\mathrm{N}$ application rates was inversely proportional to NUE. Thus, synchronization between $\mathrm{N}$ supply and its demand would increase NUE thereby reducing $\mathrm{N}$ losses (Rizwan et al., 2003). The mean NR of $54 \%$ recorded in the two years by AC, $60 \mathrm{~kg} \mathrm{~N}^{-1}$ treatment was higher than the $33 \%$ reported for the world cereal production (Magen and Nosov, 2008) and was at par with 58\% reported for maize by Niaz (2015). This rate would reduce potential nutrient losses from accelerated compost as a soil amendment (Lory and Massey, 2006). The mean $\mathrm{UE}$ of $42 \%$ from $60 \mathrm{~kg} \mathrm{~N}^{-1} \mathrm{AC}$ is within the range of 40 to $60 \%$ reported for maize by Mosier (2002), and higher than the highest obtained for maize by Niaz (2015). The ability of organic fertilizer to improve post-cropping

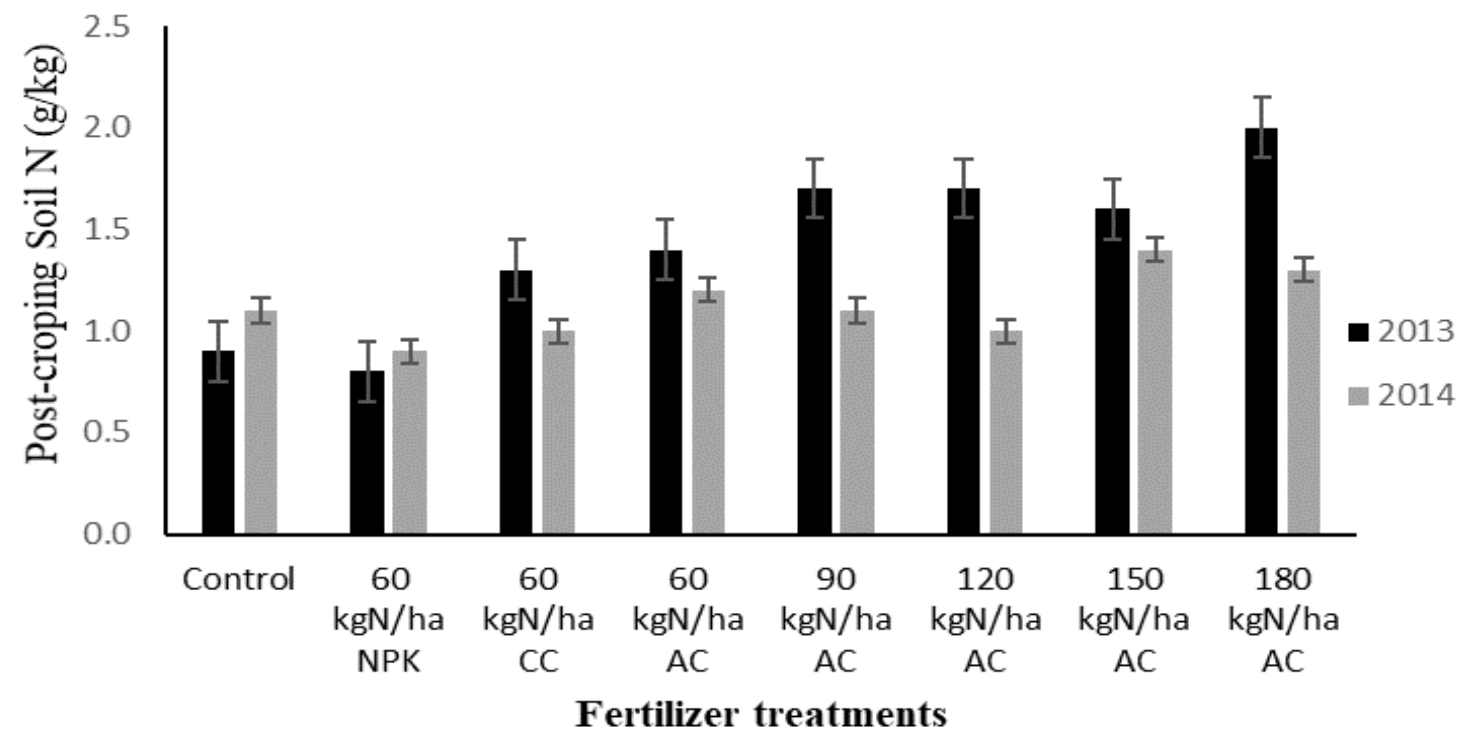

Figure 1: Effects of different rates of accelerated compost on post cropping soil total $\mathrm{N}$

Legend: NPK; NPK 15-15-15, AC; Accelerated Compost, CC; Conventional Compost Bar is Least Significant Difference (LSD) at $\alpha_{0.05}$. 
soil $\mathrm{N}$ better than mineral fertilizer is on course, because $\mathrm{N}$ release is gradual in organic fertilizers, as the material would have to go through mineralization over time, thereby conserving the $\mathrm{N}$ in the soil (Tejada and Gonzalez, 2007; George, 2011; AdeOluwa and AyanfeOluwa, 2015). This confirmed the potential of organic fertilizers to decrease the emission of nitrous oxide from fertilizer input, thereby mitigating global warming (AyanfeOluwa et al., 2014). This result is similar to earlier findings of other authors where post cropping soil $\mathrm{N}$ was improved by organic fertilisers (Natsheh and Mousa, 2014; Shehzadi et al., 2014; Anwar et al., 2015; Moyin-Jesu, 2015; Billah et al., 2018).

\section{Conclusion}

The study concluded that $60 \mathrm{~kg} \mathrm{~N}^{-1}$ accelerated compost resulted into the optimum NUE of maize and residual soil nitrogen and hence, recommended for improved maize production and reducing nitrogen loss.

\section{Acknowledgement}

The authors appreciate the Gateway Fertilizer Company, Abeokuta, Nigeria for supplying half of the accelerated compost used for this work free of charge.

\section{References}

AdeOluwa, O.O. and O.E AyanfeOluwa. 2015. Cocoa pod husk and rice husk ash options as organic potassium fertilizers for okra (Abelmoschus esculentus L. Moench) production. Ibadan Journal of Agricultural Research 10: 128-138.

Amanullah and L.K. Almas. 2009. Partial factor productivity, agronomic efficiency and economic analyses of maize in wheat-maize cropping system in Pakistan. Southern Agricultural Economics Association Annual Meetings, January 31-February 3, 2009, Atlanta, Georgia.

Anwar, S.A., M. Iqbal, A. Hassan and E. Ullah. 2015. Growth and yield of rice-wheat in response to integrated use of organic and inorganic N sources. Soil and Environment 34(2): 136-141.

AyanfeOluwa, O.E., O.O. AdeOluwa and V.O. Aduramigba-Modupe. 2014. Potentials of organic fertilizers in climate change mitigation. Nigerian Journal of Ecology 13: 27-33.

Barbanti, L., M. Grigatti and C. Ciavatta. 2010. Nitrogen release from $15 \mathrm{~N}$-labelled Compost in a sorghum growth experiment. Journal of Plant Nutrition and Soil Science 174(2): 240-248.

Billah, M.M, W. Ahmad, M. Ali and F. Khan. 2018. Effect of biochar particle size and biofertilizers on lentil (Lense culinarous M.) yield and available fractions of soil nutrients. Soil and Environment 37(2): 143-151. doi:10.25252/SE/18/71633

Bray, R.H. and L.T. Kurtz. 1945. Determination of total organic and available forms of phosphorus. Soil Science 59: 45-49.

Bremner, J.S. 1996. Nirogen-total. P.1085-1121. In: Methods of Soil Analysis, $2^{\text {nd }}$ Ed. D.I. Sparks (ed.). Soil Science Society of America, Madison, Wisconsin.

Butterbach-Bahl, K., E.M. Baggs, M. Dannenmann, R. Kiese, and S. Zechmeister-Boltenstern. 2013. Nitrous oxide emissions from soils: how well do we understand the processes and their controls? Philosophical Transactions of the Royal Society B: Biological Sciences 368(1621):20130122.

Chapman, H.D. 1965. Cation exchange capacity. P. 891901. In: Methods of Soil Analysis, part 2. No. 9. C.A. Black. (ed.). American Institute of Agronomy, Madison, Wisconsin.

Chen, W.C., K.R. Wang and X.L. Xie. 2009. Effects on distributions of carbon and nitrogen in a reddish paddy soil under long-term different fertilization treatments. Chinese Journal of Soil Science 40: 523528.

Christian, R., C.E. Angelika, G. Christoph, L. Jan, T. Frank and E.M. Albrecht. 2012. Genomic and metabolic prediction of complex heterotic traits in hybrid maize. Nature and Genetics 44: 217-220.

Dong, W., X. Zhang, H. Wang, X. Dai, X. Sun, W. Qiu and F. Yang. 2012. Effect of different fertilizer application on the soil fertility of paddy soils in red soil region of Southern China. PLoS ONE 7(9): e44504. doi.org/10.1371/journal.pone.0044504

Gee, G.W. and D. Or. 2002. Particle size analysis. P.255293. In: Methods of Soil Analysis. H. Dane and G.C. Topp (eds.). Part 4. Book series 5. Soil Science Society of America, Madison, Wisconsin.

George, S. 2011. What organic fertilizers mean to plants and soil. Michigan State University Extension. Msue.anr.msu.edu/news/what-organic-fertilizers-meanto-plants-and -soil [Accessed 30/10/2019]

Ghaly, A.E. and V.V. Ramakrishnan. 2015. Nitrogen sources and cycling in the ecosystem and its role in air, water and soil pollution: A critical review. Journal of Pollution Effects and Control 3(2): 136. doi:10.4172/2375-4397.1000136.

Hendershot, W.H., H. Lalande and M. Duquette. 1993. Ion exchange and exchangeable cations. P.167-176. In: Soil Sampling and Methods of Analysis. M.R. Carter (ed.). Lewis Publishers, London.

FFD (Federal Fertilizer Department). 2012. Fertilizer use and management practices for crops in Nigeria. P. 4041. In: Federal Ministry of Agriculture and Rural 
Development (FMA\&RD). V.O. Chude, S.O. Olayiwola, C. Daudu and A. Ekeoma, (eds.).

Kanter, D.R., X. Zhang, D.L. Mauzerall, S. Malyshev and E. Shevliakova. 2016. The importance of climate change and nitrogen use efficiency for future nitrous oxide emissions from agriculture. Environmental Research Letters 11(9): 094003. doi.org/10.1088/17489326/11/9/094003.

Kelly, V.A. 2006. Factors affecting demand for fertilizer in Sub-Saharan Africa. Agriculture and Rural Development Discussion Paper 23. The International Bank for Reconstruction and Development / The World Bank. 72 p.

Kelly, V., T. Jayne and E. Crawford. 2005. Farmers' demand for fertiliser in sub-Saharan Africa. Agriculture and Rural Development Discussion Paper 22. East Lansing: MSU. 69 p.

Lory, J.A. and R. Massey. 2006. Using manure as a fertiliser for crop production, University of Missouri, Purdue University. $11 \mathrm{p}$.

Magen, H., and V. Nosov. 2008. Putting potassium in the picture: Achieving improved nitrogen use efficiency. In: IPI-BFA-BRRI International Workshop on Balanced Fertilization for Increasing and Sustaining Productivity. 30 March - 1 April 2008, Dhaka, Bangladesh. 27 p.

Mosier, A.R. 2002. Environmental challenges associated with needed increases in global nitrogen fixation. Nutrient Cycling in Agroecosystems 63: 101-116.

Moyin-Jesu, E.I. 2015. Use of different organic fertilizers on soil fertility improvement, growth and head yield parameters of cabbage (Brassica oleraceae L). International Journal of Recycling of Organic Waste in Agriculture 4: 291-298

Murphy, J. and J.P. Riley. 1962. A modified single solution method for determination of phosphate in natural waters. Analytica Chimica Acta 27: 31-36.

Mehlich, A. 1984. Mehlich 3 soil test extractant: A modification of Mehlich 2 extractant. Communications in Soil Science and Plant Analysis 15(12): 1409-1416.

Natsheh, B and S. Mousa. 2014. Effect of organic and inorganic fertilizers application on soil and cucumber (Cucumis Sativa L.) plant productivity. International Journal of Agriculture and Forestry 4(3): 166-170.

Nelson, D.W. and L.E. Sommers. 1996. Total carbon, organic carbon and organic matter. p. 961-1010. In: Methods of Soil Analysis, ${ }^{\text {nd }}$ Ed. D.I. Sparks (ed.). Soil Science Society of America, Madison, Wisconsin.

Niaz, A., M. Yaseen, M. Arshad and R. Ahmad. 2015. Response of maize yield, quality and nitrogen use efficiency indices to different rates and application timings. Journal of Animal and Plant Sciences 25(4): 1022-1031.

Okalebo, J.R., K.W. Gathua and P.L. Woomer. 1993. Laboratory methods of soil and plant analysis: A working manual. $84 \mathrm{p}$.

Olsen, S.R. and L.A. Dean. 1965. Phosphorus. P. 10351049. In: Method of Soil Analysis, Agronomy Monogram 9, $2^{\text {nd }}$ Ed. Soil Science Society of America, Madison, Wisconsin.

Pawar, D.R., D.B. Randhe, M. Shaikh, A.K. Korde, K.A. Shinde, M.P. Yadav, A.E. Chavan and V.M. Sapkale. 2009. Laboratory testing procedure for soil and water sample analysis. Document No. SSD/GL.01. 133 p.

Pikul, J.L., L. Hammack and W.E. Riedell. 2005. Corn yield, nitrogen use and corn rootworm infestation of rotations in the northern Corn Belt. Agronomy Journal 97: 854-863.

Rizwan, M., M. Maqsood, M. Rafiq, M. Saeed and Z. Ali. 2003. Maize (Zea mays L.) response to split application of nitrogen. International Journal of Agriculture and Biology 5(1): 19-21.

Schenk, M.K. 2006. Nutrient efficiency of vegetable crops. Acta Horticulture 700: 25-38.

Sharma, N.K, R.J. Singh and K. Kumar. 2012. Dry matter accumulation and nutrient uptake by wheat (Triticum aestivum L.) under poplar (Populus deltoides) based agroforestry system. International Scholarly Research Notices Agronomy Vol. 2012, Article ID 359673, 7 pages. doi.org/10.5402/2012/359673.

Shehzadi, S, Z. Shah and W. Mohammad. 2014. Residual effect of organic wastes and chemical fertilizers on wheat yield under wheat-maize cropping sequence. Soil and Environment 33(2): 88-95.

Singh, Y.V. and B.K. Mandal. 2000. Rate of mineralization of Azolla, other organic materials and urea in water logged soils. Tropical Agriculture (Trinidad) 77 (1): 119-122.

Smyth, A.J. and R.F. Montgomery. 1962. Soil and land use in central western Nigeria. Government Printer, Ibadan, Western Nigeria. 264 p.

Soil Survey Division Staff. 1993. Soil Survey Manual. U.S. Dept. of Agriculture Handbook No. 18. U.S. Govt. Printing Office, Washington, DC.

Tejada, M. and J.L. Gonzalez. 2007. Application of different organic wastes on soil properties and wheat yield. Agronomy Journal 99: 1557 - 1606.

Thomas, G.W. 1982. Exchangeable cations. p. 159-165. Methods of soil analysis. A.L. Page, R.H. Miller and D.R. Keeney, (eds.). Part 2. Agronomy Monogram 9. Soil Science Society of America, Madison, Wisconsin.

Thomas, G.W. 1996. Soil pH and soil acidity. p. 475-490. In: Methods of Soil Analysis, Chemical Methods. Part 
3. D.I. Sparks, (ed.). Soil Science Society of America, Madison, Wisconsin.

UNDESA (United Nations, Department of Economic and Social Affairs, Population Division). 2015. World Population Prospects: The 2015 Revision, Key Findings and Advance Tables. Working Paper No. ESA/P/WP.241.

Varvel, G.E. and T.A. Peterson. 1990. Nitrogen fertiliser recovery by corn in monoculture and rotation systems. Agronomy Journal 82: 935-938.

Wanyama, I., V.A. Ochwoh, E. Nankya and P.J.A. Van Asten. 2015. Optimisation of major nutrients (N, P and $\mathrm{K})$ for lowland rice production in Eastern Uganda. International Journal of Agronomy and Agricultural Research 7(2): 218-227.
Zingore, S. 2016. Influence of soil fertility variability and nutrient source on maize productivity and nitrogen use efficiency on smallholder farms in Zimbabwe. Proceedings of the 2016 International Nitrogen Initiative Conference, "Solutions to improve nitrogen use efficiency for the world", 4-8, December 2016, Melbourne, Australia. 